Отримано: 20.10.2019 р.

Прорецензовано: 01.11.2019 р.

Прийнято до друку: 05.11.2019 р.

e-mail: ignatusha1@yandex.ua

DOI: $10.25264 / 2409-6806-2019-29-49-53$
Ігнатуша Г. Внесок Олександра Воронина у національне відродження України. Наукові записки Національного університету «Острозька академія». Серія «Історичні науки». Острог, 2019. Вип. 29. С. 49-53.

УДК 94(477)-86«19/20»

\title{
Григорій Ігнатуша
}

\section{ВНЕСОК ОЛЕКСАНДРА ВОРОНИНА У НАЦОНАЛЬНЕ ВІДРОДЖЕННЯ УКРАЇНИ}

У статті проаналізовано діяльність представника української діаспори в США Олександра Воронина, щуо була спрямована на наџіональне відродження України. Розглянуто створення та проведення ним передач на радіостанціях «Свобода» та «Голос Америки» протягом 80-90-х рр. ХХ ст. Окрема увага приділяється участі Олександра Воронина у відзначенні Тисячоліття хрещення України-Русі.

Ключові слова: Україна, діаспора, національне відродження, релігія, традиції.

\section{Hryhorii Ihnatusha}

\section{ALEXANDER VORONYN'S CONTRIBUTIONIN NATIONAL REVIVAL OF UKRAINE}

The personality of Aleksandr Voronyn is almost not studied, and for this reason the author of the research has made an attempt to illustrate certain aspects of the life of this journalist, editor, clergyman and statesman. This article includes the analysis of the activities of Aleksandr Voronyn, the representative of Ukrainian diaspora in the USA, which was aimed for the national renascence of Ukraine. His work in the Metropolitanate of UOC of the USA in South Bound Brook town and the first volume of the documentary publication "Martyrology of the Ukrainian Churches V. 1. The Ukrainian Orthodox Church", which was compiled by him, demonstrate his professional skills. The idea of organization of the religious and educational publishing house "Resurrection" belongs to A. Voronyn.

The article reviews the history of $A$. Voronyn's creation and hosting of broadcasts on such radio stations as "Svoboda" (he was a presenter of a series of programs "From the Chronicle of the Ukrainian Orthodox Church") and "Voice of America" (he carried out the preparation of the program "The Voice of the Ukrainian Autocephalous Orthodox Church Speaking”, the first broadcast of which was opened by the Metropolitan of the Ukrainian Orthodox Church in the United States Mstyslav (Skrypnyk), who later became the Patriarch of the UAOC) during the 1980s-1990s. In this way, broadcasting was one of the ways of dialog between the Ukrainian diaspora and Ukraine, particularly during the time of the Soviet Union.

Particular attention is paid to the participation of Alexander Voronyn in the events dedicated to the celebration of the Millennium of Baptism of all Ukraine-Rus, which were held in the USA in 1985-1989. Voronyn prepared and made several reports devoted to focal points of Ukrainian church history at several scholarly conferences. He has also been the author of the texts and commentaries to the exhibition "The Icon in Ukraine", which was took place within the framework of the conference organized thanks to the Ukrainian Research Program of the University of Illinois (20-25 June 1988). The author considers and regards such activity as the apogee of his activity in the religious field.

It was concluded that A. Voronyn was a devoted patriot of Ukraine whose versatile activities (scholarly, educational, organizational, journalistic, charitable) were aimed at the revival and preservation of Christian values of the Ukrainian people and building a bridge between Ukraine and the Ukrainian Diaspora.

Key words: Ukraine, Diaspora, national revival, religion, traditions.

Проблеми взаємовпливів і взаємозв’язків українців у межах світової спільноти, України та її діаспори набули виразної актуальності в умовах розбудови української незалежної держави. Почали ак- 
тивніше вивчатися й історичні аспекти цих зв'язків, як такі, що проливають світло на генезу і характер процесів зазначеної взаємодії.

Неабиякий інтерес викликають події, що передували проголошенню державної незалежності України і ролі у них української діаспори, ії окремих представників, інституцій, спільнот. Ці події відбувалися в контексті конкретних історичних умов, специфічних складнощів і проблем. На них суттєво впливали обставини державно-політичних систем, ідеологічних позицій, комунікаційних можливостей. Комунікації між українством Радянського Союзу та діаспори мали значні складнощі. По-перше, через заборону вільного діалогу між громадянами СРСР та світом. По-друге - через технічні можливості, які тоді були значно нижчими. 3 огляду на це ми вкрай недостатньо знаємо про осіб української діаспори, які активно долучилися до українського відродження та стали його часткою. Пам'ятаючи про це, намагаймося пролити світло на активну діяльність творців відродження України, проявлену поза їі межами. Лише таким чином можемо зруйнувати мур упередженості, який історично формувався у радянському суспільстві та відділяє Україну від іiї вірних синів.

Проголошення незалежності не було явищем спонтанним. Незалежність постала внаслідок тривалої боротьби за українську державність. Її прояви були різними, однак мали одну мету. Хтось брався до зброї та протягом тривалого часу прямим протистоянням намагався відстояти українську державність, але були також і інші патріоти - люди, які своїми думками та словом поступово формували усвідомлення необхідності самоідентифікації українства. Серед останніх був Олександр Воронин - талановитий журналіст, редактор, релігійний та громадський діяч. До розвідки про його діяльність нас спонукало питання, хто і яким чином наближав Незалежність України.

Особистість Олександра Воронина майже не досліджено. Йому присвячені лише короткі біографічні штрихи в рамках проекту «Енциклопедія української діаспори» [6] та окремі літературознавчі замальовки. Своїм завданням вбачаємо ліквідацію цієї білої плями української історії. Варто говорити, що поштовхом до активізації національно-культурницької діяльності Олександра Воронина стала суспільно-політична ситуація в світі та в Радянському Союзі, зокрема.

На кінець 80-х років XX ст. посилилися відцентрові тенденції в Радянському Союзі. Цей факт вселяв оптимізм у думки щирих патріотів та борців за незалежну Україну. Така ситуація стала потужним імпульсом діяльності Олександра Воронина. Він вбачав за можливе донести співвітчизникам в Україні свої просвітницькі, національно-релігійні, християнські, гуманістичні ідеї. Шляхом донесення цих ідей із-за океану він як журналіст, передусім, бачив радіохвилі. У такий спосіб Олександр Воронин намагався у межах свого розуміння та компетенції сприяти національному пробудженню українського радянізованого суспільства.

Олександрові Воронину випала нелегка доля. Ще за юнацьких років він змушений був покинути рідний край. Цьому були вагомі причини.

Батько Олександра - Олексій Варавва - був досить відомим письменником (псевдонім - Олекса Кобець). За його авторства побачили світ багато дитячих віршів, казок та оповідань, збірки «Ряст» та «Сходить сонце», роман «Люлі-люлі дитино», твір «Живім у згоді» та найбільша праця Олекси Кобця - автобіографічний роман «Записки полоненого» [1; 4]. Крім цього, Олексій Варавва здійснив чимало перекладів творів Льва Толстого та Максима Горького українською мовою.

На сьогодні нам добре зрозуміло, що будь-якому письменнику, який мав національні орієнтири складно було існувати в радянському суспільстві. Тим більше - творити у власному руслі, не дотримуючись лінії «Спілки письменників СРСР». Тому, шукаючи свободи для себе та своєї сім’ї, Олексій Варавва вирішив емігрувати. Це рішення довелося приймати за складних умов німецької окупації України під час Другої світової війни перед загрозою звинувачень у співпраці з редакцією газети «Нова Україна». Так почалася закордонна історія Олександра Воронина. Спершу була Німеччина, де Олександр отримав освіту у Богословській академії УАПЦ (м. Мюнхен), потім - США. Зі Сполученими Штатами Америки пов’язаний найтриваліший період в житті О. Воронина. Саме на теренах цієї країни він зумів реалізуватися як релігійний мислитель, літератор-професіонал та український патріот.

Професіоналізм О. Воронина проявився у його праці в митрополії УПЦ США у місті Саут-БаундБрук. Зокрема, завдяки його плідній праці як упорядника, побачив світ перший том потужного документального видання - «Мартирологія українських церков Т. 1. Українська Православна Церква» (1987 р.). Ця праця донині не втратила своєї інформативної і меморіальної вартості. 
Талант Олександра добре характеризують його радіоефіри та журналістська діяльність, ідея організації релігійно-просвітницького видавництва «Воскресіння». Як великого патріота Олександра репрезентує благодійна та просвітницька діяльність.

3 проголошенням курсу М. Горбачова на перебудову, в Радянському Союзі наприкінці 80-х років почалася демократизація суспільного життя. 3 одного боку, цей фактор значною мірою вплинув на зв'язок України $з$ діаспорою. 3 іншого - став одним із чинників ліквідації КПРС та розпаду СРСР. Українці отримали змогу почути голос своїх співвітчизників з-за Океану, який доносили заборонені раніше радіохвилі, що щільно глушилися радянськими спецслужбами [5, с. 196].

Наприкінці 80-х pp. XX ст. в радянській Україні вперше почули голос Олександра Воронина. Передачі за його участю випускали українські редакції всесвітньо відомих радіо - «Свобода» та «Голос Америки». Ці передачі були спрямовані на Україну й окреслювали один із найважливіших напрямків громадсько-релігійної діяльності Олександра Воронина: пробудження незалежної думки, національної гідності та утвердження загальнолюдських цінностей в радянському суспільстві. Засобом цього пробудження і предметом безпосередньої уваги О. Воронина стала популяризація замовчуваних і фальсифікованих радянською владою сторінок вітчизняної церковної історії. Зокрема, протягом 1989-1992 рр. на радіо «Свобода» він провів цикл передач «3 літопису Української Православної Церкви».

Водночас О. Воронин здійснював підготовку щонедільної одногодинної програми «Говорить голос Української Автокефальної Православної Церкви», започаткованої радіостанцією «Голос Америки». Ця програма почала виходити у світ з Великодня 1989 р. Ї̈ї допомагали готувати кілька журналістів української редакції «Голосу Америки». Першу передачу цієї програми відкрив Митрополит Української Православної Церкви (УПЦ) в США Мстислав (Скрипник) - майбутній перший Патріарх Української Автокефальної Православної Церкви (УАПЦ). Він пояснив, що нова радіопрограма - «Це міст безпосереднього зв'язку з нашими братами і сестрами в Україні, які зберегли у своїх серцях любов до Бога і рідної Церкви та прагнуть її нового відродження» [7, с. 259]. Подібний спосіб спілкування між українською діаспорою та Україною поставав як один з небагатьох можливих. Адже Радянський Союз максимально обмежував своїх громадян від контактів із Заходом, а відтак - гальмував поширення вільної думки і плюралістичного світогляду.

Природно, що діаспора та західні громадські й державні інституції поширювали інформаційну роботу у царині релігії. Адже церква була традиційною суспільною організацією, а релігія - органічним виявом приватного та суспільного життя громадян у всіх країнах світу. Ї̈і соціальна значимість зберігалася віками. Лише у Радянському Союзі з часів утвердження більшовицького режиму впроваджувався гігантський соціальний експеримент позбавлення суспільства релігійності. Проти цього антиприродного експерименту радянських комуністів Захід поставав усіма можливими засобами солідарної протидії. Звернення до історії церкви в українських землях було покликом українському народові до історичної пам'яті та переосмислення маргінальної ролі, відведеної йому комуністичними вождями.

У зазначеному контексті готували радіопередачі й інші автори. Зокрема, у той самий час їх готував для українських слухачів відомий греко-католицький діяч Атанасій Великий. Його передачі «3 літопису християнської України» регулярно виходили в ефір на радіо «Ватикан». Згодом їх матеріал автор упорядкував та опублікував серійним виданням [2].

Подібним чином з лекціями-нарисами в радіоефірі виступав для православного загалу і Олександр Воронин. Він також мав ідею опрацювати та видати радіо-скрипти у формі окремої книжки. Проте цей задум, на жаль, так і не здійснився. Завдяки згаданим передачам голос О. Воронина став пізнаваним. У нього сформувалася широка слухацька аудиторія. Передачі слухали як віруючі, так i «невіруючі».

Свідченням громадського визнання Олександра Воронина в Україні вже в переддень державної незалежності стало використання його праць, цитування його висловлювань, публікація його історико-публіцистичних доробків на шпальтах однієї з найпрогресивніших газет «Літературна Україна» [3]. Старші покоління добре пам'ятають, як охоронці радянського політичного режиму докладали зусиль, аби нейтралізувати вплив небезпечного для себе живого інформаційного потоку. Примітною у цьому відношенні вбачаємо згадку прізвища О. Воронина на сторінках «Прес-бюлетеня», що поширювався з центру таємними каналами обкомам партії напередодні краху КПРС та розвалу СРСР. «Прес-бюлетень» містив «єдиноправильні» оцінки суспільних явищ і подій, які відбувалися за кор- 
доном СРСР і мали відношення до життя українців в УРСР та в усьому світі. Посеред іншого він характеризував діяльність зарубіжних радіостанцій, спрямованих на Україну, як «підривні радіоголоси». Навіть подавав спеціальні статті про них. У № 10 такого «Прес-бюлетеня» за 1989 р. повідомлялося, з посиланням на тижневик «Українські вісті» (Нью-Йорк) від 9 липня, що 30 квітня 1989 р. Українська Православна Церква у США розпочала радіопередачі, спрямовані на УРСР. Вони репрезентували окрему програму «Голос УАПЦ». Ї̈̈ головним редактором був Олександр Воронин. Наведений факт переконує, що думки та ідеї, якими жив Олександр Воронин, і якими ділився зі своїми далекими співвітчизниками, були вкрай небезпечними радянській системі. Їх боялися. Їх намагалися нейтралізувати. Вони наповнювали русло української ідентичності та наближали воскресіння національної свідомості.

Далеко від батьківщини, за Океаном, Олександр Воронин зумів розгорнути активну різновекторну діяльність, маючи на меті відродження глибоких національних традицій українського народу та його християнських цінностей. Маємо свідчення щодо участі Олександра Воронина у наукових заходах 3 приводу відзначення 1000-ліття хрещення Русі, які пройшли у Сполучених Штатах Америки у 1985-1989 рр. Олександр Воронин був учасником першої з конференцій, організованої за океаном Комітетом наукового відзначення ювілею тисячоліття християнства Русі-України 1988-1989 рр. Конференція відбулася 15-17 червня 1985 р. в американському містечку Саут-Баунд-Брук. Як відомо, це місто є центром Української Православної Церкви у США. Саме там знаходиться всесвітньо відомий осередок УПЦ: церква-пам'ятник св. апостола Андрія Первозванного, цвинтар-пантеон, бібліотека, книжковий склад, музей, Дім української культури, семінарія св. Софії та адміністративний центр 3 канцелярією Консисторії - осідок митрополитів - першоієрархів українських церков в США.

Магістр богослов’ я Олександр Воронин був серед перших доповідачів на цій поважній за складом учасників та важливій за проблематикою конференції. Він виступив із доповіддю «Християнство і народ, перших сто років» [8, с. 488]. Заявлена тематика підкреслює намагання автора осмислити сутнісні питання взаємодії та інтеграції християнської віри з давньоруським суспільством, шляхи, способи та результати формування релігійної свідомості на християнських засадах. Вона характеризує О. Воронина як науковця, котрий прагнув до з'ясування глибинної природи суперечливих питань, реконструкції соціального контексту історичних подій, встановлення їхньої української специфіки.

У червні 1988 р. О. Воронин взяв участь у ще одному поважному науковому заході 3 нагоди 1000-ліття хрещення Русі. Це була конференція, яку організували завдяки Українській дослідницькій програмі Іллінойського університету 20-25 червня 1988 р. Директором заходу виступав професор Іллінойського університету Дмитро Штогрин. О. Воронин задекларував себе у програмі конференції незалежним дослідником із міста Сільвер Спрінг зі штату Меріленд. Він виступив 3 промовою «Константинополь і православна церква в Україні після Переяслава». Цю доповідь автор виголосив українською мовою. Цікава деталь. У ході конференції експонувалася виставка «Ікона в Україні». Її репрезентувала фундація родини Чопівських під керівництвом Славка Новицького. Автором текстів і коментарів до цієї виставки був також Олександр Воронин [8, с. 499].

5 серпня 1988 р. науково-духовною доповіддю на тему «Православна церква на Україні після Переяславської домови» Олександр Воронин відкрив наукову конференцію у Баунд-Бруку [8, с. 500]. Тими днями - 5-7 серпня Українська Православна Церква у США і діаспорі урочистими святкуваннями завершувала Святий ювілейний рік, проголошений з нагоди тисячоліття хрещення РусиУкраїни [8, с. 65].

Тематика наукових доповідей О. Воронина у 1988 р. свідчила про його увагу до вузлових моментів української церковної історії, усталення його наукового інтересу до проблематики історії церкви часів визвольної війни українського народу середини XVII ст. Цю проблематику, як і проблематику християнізації Русі, варто віднести до ключових для розуміння змін у релігійній свідомості українського суспільства. Відмінними були хронологічні рамки предмета дослідження. Вони свідчили про пізнавальний рух науковця від однієї до іншої вагомої проблеми історії української церкви та розуміння ним значимості аналізованих подій середини XVII ст. Саме ці події справили потужний вплив на подальший хід української історії ранньомодерної доби та пізнішого часу.

Під час ювілейних заходів з нагоди тисячоліття хрещення Русі, Олександр Воронин покликувався високими почуттями свого християнського обов'язку, почуттями сина України, почуттями людини і громадянина. Він був активний у громадсько-церковній роботі, органічно використовував свої науко- 
ві знання у практиці відродження церкви в Україні. Зазначена діяльність виступає піком релігійної активності Олександра Воронина.

Таким чином, робота Олександра Воронина у митрополії УПЦ США у місті Саут-Баунд-Брук була працею активного, різностороннього, непересічного релігійного діяча. Ця активність була постійною, але особливо виразно ми її спостерігаємо від 80-х років XX ст., в момент відзначення Тисячолітнього ювілею хрещення України-Русі. Саме тоді найбільшим чином проявився його яскравий релігійно-дослідницький, популяризаторський, організаторський, просвітницький талант.

Журналістська діяльність Олександра Воронина найпершим чином була спрямована на Україну. Він мав чітку і високу мету - просвітити українство, донести до широкої слухацької аудиторії загальнолюдські християнські цінності. Справа, яку робив О. Воронин була вкрай важливою, враховуючи умови в яких жили українці. Кінець 80 -х рp. XX ст. був непростим часом в економічному та національно-культурному сенсі. Через свої радіопередачі Олександр намагався підтримати співвітчизників, вселити в них віру на гідне життя у вільній незалежній державі, в якій будуть вшановані загальнолюдські цінності, національно-культурної ідеали, демократичні свободи. Його прагнення нам зрозумілі. Олександр Воронин мав на меті збудувати місток єднання між українцями України та українцями діаспори.

\section{Список використаних джерел та літератури:}

1. Варавва О. Олекса Петрович Варавва-Кобець - людина. В кн.: Кобець О. Коли задзвонить великий дзвін. Оповідання, спогади. Черкаси: Сіяч, 1993. С. 3-7.

2. Великий А. Г., ЧСВВ. 3 літопису християнської України. Рим; Львів: Місіонер, 1998. Т. I: IX-XI ст. 278 с.

3. Воронин О. Автокефалія Української Православної Церкви. Літературна Україна. 1991. 10 жовтня.

4. Дорошенко Т. Олекса Кобець: талант - у багатогранності поета, прозаїка, драматурга, перекладача і педагога. Дніпрова Зірка. Канівський тижневик. 1 травня 2011. URL: http://dniprowazirka.com.ua/page.php?c=1840 (дата звернення: 15.10.2016).

5. Каганов Ю. О. «Ворожі голоси»: ідеологічне протистояння на радіохвилях у радянській Україні (друга половина XX ст.). Наукові прачі історичного факультету Запорізького начіонального університету. Запоріжжя, 2013. Вип. XXXV. С. 193-201.

6. Маркусь В. Воронин Олександр. Енщиклопедія української діаспори / гол. ред. В. Маркусь, співред. Д. Маркусь. Нью-Йорк; Чикаго, 2009. Кн. 1. С. 132.

7. Степовик Д. Патріарх Мстислав: життя і архіпастирська діяльність. Київ: Мистецтво, 2007. 448 с.

8. Тисячоліття Християнства в Україні. Урочистості 1988 року / гол. ред. Осип Зінкевич. Нью-Йорк: Крайовий комітет Тисячоліття Християнства в Україні, 1992. 524 с.

\section{References}

1. Varavva O. Oleksa Petrovych Varavva-Kobets - liudyna. V kn.: Kobets O. Koly zadzvonyt velykyi dzvin. Opovidannia, spohady. Cherkasy: Siiach, 1993. S. 3-7.

2. Velykyi A. H., ChSVV. Z litopysu khrystyianskoi Ukrainy. Rym; Lviv: Misioner, 1998. T. I: IX-XI st. 278 s.

3. Voronyn O. Avtokefaliia Ukrainskoi Pravoslavnoi Tserkvy. Literaturna Ukraina. 1991. 10 zhovtnia.

4. Doroshenko T. Oleksa Kobets: talant - u bahatohrannosti poeta, prozaika, dramaturha, perekladacha i pedahoha. Dniprova Zirka. Kanivskyi tyzhnevyk. 1 travnia 2011. URL: http://dniprowazirka.com.ua/page.php?c=1840 (data zvernennia: 15. 10. 2016).

5. Kahanov Yu. O. «Vorozhi holosy»: ideolohichne protystoiannia na radiokhvyliakh u radianskii Ukraini (druha polovyna XX st.). Naukovi pratsi istorychnoho fakultetu Zaporizkoho natsionalnoho universytetu. Zaporizhzhia, 2013. Vyp. XXXV. S. 193-201.

6. Markus V. Voronyn Oleksandr. Entsyklopediia ukrainskoi diaspory/ hol. red. V. Markus, spivred. D. Markus. Niu-York; Chykaho, 2009. Kn. 1. S. 132.

7. Stepovyk D. Patriarkh Mstyslav: zhyttia i arkhipastyrska diialnist. Kyiv: Mystetstvo, 2007. 448 s.

8. Tysiacholittia Khrystyianstva v Ukraini. Urochystosti 1988 roku / hol. red. Osyp Zinkevych. Niu-York: Kraiovyi komitet Tysiacholittia Khrystyianstva v Ukraini, 1992. $524 \mathrm{~s}$. 